\title{
Effects of excluding sea turtle herbivores from a seagrass bed: Overgrazing may have led to loss of seagrass meadows in Bermuda
}

\author{
James W. Fourqurean ${ }^{1, *}$, Sarah Manuel ${ }^{2}$, Kathryn A. Coates ${ }^{2}$, \\ W. Judson Kenworthy ${ }^{3}$, Struan R. Smith ${ }^{4}$ \\ ${ }^{1}$ Marine Science Program, Department of Biology, and Southeast Environmental Research Center, \\ Florida International University, North Miami, Florida 33181, USA \\ ${ }^{2}$ Applied Ecology Section, Department of Conservation Services, Bermuda Ministry of Environment and Sports, Smiths, \\ FL 04, Bermuda \\ ${ }^{3}$ Center for Coastal Fisheries and Habitat Research, NCCOS, NOAA, Beaufort, North Carolina 28516, USA \\ ${ }^{4}$ Bermuda Aquarium, Museum and Zoo, Department of Conservation Services, Bermuda Ministry of Environment \\ and Sports, Smiths, FL 04, Bermuda
}

\begin{abstract}
Protecting a Thalassia testudinum-dominated seagrass meadow from grazing by sea turtles for 1 yr caused an increase in the biomass of seagrasses and an increase in the structural complexity of the seagrass canopy, as the length and width of the seagrass blades increased in comparison to grazed plots. Plots from which turtles were excluded had higher rates of primary production on a per-shoot or areal basis, but the relative growth rate was not affected. The leaves of seagrasses protected from grazing had lower concentrations of nitrogen and phosphorus than grazed blades, but the storage of soluble carbohydrates in the rhizomes increased markedly in the protected plots, suggesting that reduced carbon fixation caused by the removal of photosynthetic leaves is the mechanism for seagrass decline in heavily grazed meadows, not nutrient limitation as has been suggested in the literature. The continued grazing of sea turtles in our plots did not lead to significant changes in seagrass shoot density or nutrient content over the $1 \mathrm{yr}$ duration of our experiments. The decreased canopy cover and the shorter, thinner seagrass leaves induced by sea turtle grazing in our experimental plots suggest that the progressive narrowing and thinning of seagrasses observed before the collapse of 2 offshore seagrass beds in Bermuda during the 1990s may have been in response to repeated and intense grazing of those seagrass beds.
\end{abstract}

KEY WORDS: Caribbean Coastal Marine Productivity Program • CARICOMP · Thalassia testudinum • Nutrient content $\cdot$ Soluble carbohydrates $\cdot$ Productivity

\section{Resale or republication not permitted without written consent of the publisher}

\section{INTRODUCTION}

Populations of the green sea turtle Chelonia mydas in the Atlantic Ocean are recovering rapidly as a result of conservation efforts directed at this historically overharvested species, with population growth rates of between 4.1 and $16.1 \%$ per year at 2 of the important Atlantic rookeries (Chaloupka et al. 2008). Green sea turtles are mainly herbivorous, and they consume large amounts of seagrass (Thayer et al. 1984). It has been suggested that, historically, grazing by sea turtles played an important role in the maintenance of healthy seagrass beds by removing the seagrass canopy and preventing the build-up of organic matter in seagrass beds, and that the loss of this grazing in the 19th century may be a cause of mass die-offs of seagrasses seen in the 20th century (Jackson et al. 2001, Bjorndal \& Jackson 2003). Now that sea turtle populations are increasing, it is reasonable to assume that the impact of sea turtles on the structure and function of seagrass beds may be changing.

In the tropical western Atlantic and the Caribbean, adult green sea turtles feed primarily on the newlyemerged leaves of the seagrass Thalassia testudinum 
(Williams 1988, Bjorndal 1997). Whether to reject the relatively low nutrient content of old seagrass leaves (Bjorndal 1980) or to avoid the calcareous encrusting epiphyte communities on those old blades (Zieman et al. 1984), green sea turtles often clip seagrass shoots to within approximately $1 \mathrm{~cm}$ of the sediment surface, allowing the leaves to float away; they then repeatedly graze the newly-produced, unepiphytized, high nutrient-content seagrass leaves that grow after the clipping (Bjorndal 1997). Thayer et al. (1984) surmised that these repeated grazing events would stress the seagrasses, so that leaf widths would decrease, short shoot density would decline, leaf production would decline, and recycling of nutrients through a local detritus cycle would be interrupted. Further, they suggested that internal stores of carbohydrates and proteins would be mobilized from the rhizomes to grow new leaves, and that the repeated cropping of new leaves would eventually lead to a decline in the nutrient content of the seagrass as stores were depleted, resulting in poor food quality and decreased food production for the turtles. These declines would then cause the turtles to abandon that grazing patch and begin the cultivation of a new grazing site. However, recent experimental work has shown that growth rates (Moran \& Bjorndal 2005) and nutrient content (Moran \& Bjorndal 2007) of leaves of $T$. testudinum do not decline after $16 \mathrm{mo}$ of simulated turtle grazing in the Bahamas, suggesting that seagrass beds can be quite resilient in the face of turtle grazing pressure.

Bermuda is an isolated archipelago that, despite its temperate latitude (ca. $32.3^{\circ} \mathrm{N}, 64.8^{\circ} \mathrm{W}$ ), has nearshore benthic marine communities dominated by coral reefs and tropical seagrass beds (Murdoch et al. 2007). Bermuda has a juvenile green sea turtle population that preferentially feeds in seagrass beds (Godley et al. 2004). Juvenile green sea turtles spend up to $14 \mathrm{yr}$ in Bermuda before returning to natal beaches in North America, Central America and the Caribbean to breed (P. A. Meylan, A. B. Meylan \& J. A. Gray, Bermuda Turtle Project (BTP) unpubl. data). While analyses of the trajectories of green sea turtle populations in Bermuda are incomplete and equivocal, anecdotal evidence suggests that the populations increased slightly between 1999 and 2004, but that the numbers were lower than 40 yr ago (Godley et al. 2004).

Seagrass beds have declined precipitously on the Bermuda Platform, especially in offshore sites distant from obvious human impact (Murdoch et al. 2007) where turtles were abundant (BTP unpubl. data). Evidence of grazed seagrasses-i.e. seagrass shoots clipped evenly off at a height of about $2 \mathrm{~cm}$ above the sediment surface - is very common in the seagrass beds of the platform. Observations of intense turtle grazing (S. R. Smith pers. obs.) were made from 1998 to
2000 at 2 offshore Thalassia testudinum-dominated seagrass beds that were monitored as part of the CARICOMP (Caribbean Coastal Marine Productivity Program) network (Smith 1998, Alcolado et al. 2001). The seagrasses at the Bermuda CARICOMP site began to decline in 1996 or 1997, until both beds (originally ca. 1.1 ha total) disappeared, leaving an unvegetated sandy bottom with exposed remnants of the roots and rhizomes of the former seagrasses. Once these seagrass beds disappeared, the turtles abandoned the area as well (BTP unpubl. data), and the seagrass has not yet recovered.

We hypothesize that the type of herbivory we commonly observe in Bermuda seagrass beds is caused by green turtles, and that this grazing has a detrimental effect on the seagrass beds and may be an explanation for the recent losses of seagrasses from broad areas of the Bermuda Platform. To test this hypothesis, we set up cages designed to exclude large-bodied herbivores from a heavily grazed area while allowing smaller herbivores such as the bucktooth parrotfish Sparisoma radians and juvenile parrotfishes of other species (Scarus spp.), and the 2 sea urchins Tripneustes ventricosus and Lytechinus variegatus access to the seagrass in the cages. Following $1 \mathrm{yr}$ of protection from herbivory by large-bodied herbivores, we compared aspects of the status of the seagrass bed and vigor of the seagrass plants with the same measures from plants in unprotected control areas.

\section{MATERIALS AND METHODS}

Study site. In 1993, 2 seagrass monitoring stations were established in a dense, Thalassia testudinumdominated, ca. $5 \mathrm{~m}$ deep seagrass meadow located ca. $10 \mathrm{~km}$ off the island of Bermuda in the middle of the Bermuda Platform (north site: $32.4008^{\circ} \mathrm{N}, 64.7994^{\circ} \mathrm{W}$, south site: $32.3995^{\circ} \mathrm{N}, 64.7954^{\circ} \mathrm{W}$ ) as part of the Caribbean-wide CARICOMP network (CARICOMP 1997, Smith 1998, Alcolado et al. 2001). Following that network's protocols, the morphology and short shoot density (among other parameters) were determined repeatedly over the period from 1993 to 2001, when the stations were abandoned because of the disappearance of the seagrass meadows. Mean leaf widths and lengths of T. testudinum, and the 2-sided Leaf Area Index (LAI) were measured in September of 1994, 1996, 1998, and 2000. By 2001, the seagrasses had disappeared from both CARICOMP sites. In our subsequent exclusion experiments, we used methods that would provide comparable measures of these parameters.

Experimental set-up. In September 2008, 6 experimental plots were placed at $10 \mathrm{~m}$ intervals along a $60 \mathrm{~m}$ transect in a heavily grazed seagrass zone very close to a coral reef near Chub Head Beacon on 
the Bermuda Platform $\left(32.2716^{\circ} \mathrm{N}, 64.9661^{\circ} \mathrm{W}\right)$. This grazed zone was established by sea turtles sometime between 1997 and 2006, as we discovered the obviously heavily grazed zone when we established a permanent monitoring site here in December 2006. There was no difference in apparent seagrass density between the currently grazed zone and the adjacent ungrazed seagrass bed evident in a fine-scale aerial photo taken in June 1997. Nearest the reef, the grazed zone consists of a 10 to $16 \mathrm{~m}$ wide unvegetated halo similar to the reef halos commonly encountered in the Caribbean (sensu Tribble 1981). The unvegetated halo grades abruptly into a heavily grazed Thalassia testudinum meadow. Further from the reef, the heavily grazed zone transitions into a dense T. testudinumdominated meadow with sparsely distributed Syringodium filiforme and Halodule sp. The water was ca. $3 \mathrm{~m}$ deep at the site. The 6 plots were randomly assigned to 1 of 2 treatments, megaherbivore exclusion (3 plots) or control (3 plots).

Megaherbivore exclusion cages (Fig. 1) were $2 \times 2 \mathrm{~m}$ wide with a height of $30 \mathrm{~cm}$ above the sediment surface, and were constructed of $20 \times 20 \mathrm{~cm}$ galvanized steel mesh $(0.6 \mathrm{~cm}$ diameter wires). The vertical sides of the cages were constructed of the same material and extended into the sediment to prevent large animals from entering the cages from the sides. The wide spacing of the mesh effectively kept out sea turtles while allowing access by smaller-bodied animals such as parrotfishes, and had a negligible impact on the amount of light reaching the seagrass beds. Fouling of the cage mesh was minimal during the 1 yr experiment. Control areas (grazed plots) were delineated by a $2 \times 2 \mathrm{~m}$ square of $1.25 \mathrm{~cm}$ galvanized steel rod suspended horizontally $30 \mathrm{~cm}$ above the sediment surface that served to demarcate the control plots and also to provide a presence of galvanized steel in the seagrass bed while allowing access by all sizes of potential herbivores. This treatment represents a 'cage control' as it mimics the presence of a full cage but does not interfere with grazing activity. Additionally, we collected data from haphazardly chosen locations in the adjacent (ca. $20 \mathrm{~m}$ distant) ungrazed seagrass bed.

At the initiation of the experiment and after $1 \mathrm{yr}$ of megaherbivore exclusion, shoot density of seagrasses was measured by haphazardly tossing a $20 \times 20 \mathrm{~cm}$ sampling quadrat 10 times in each cage and control plot, as well as in the adjacent, ungrazed seagrass bed. All seagrass species encountered in the quadrats were identified and the number of seagrass short shoots was counted.

Sampling. At the initiation of the experiments, and again after the exclusion cages had been in place for $1 \mathrm{yr}$, we sampled seagrass shoots in each plot to assess the morphology and nutrient content of the seagrass leaves. For a more detailed description of the methods, see Fourqurean et al. $(2001,2005)$. Five short shoots of Thalassia testudinum were haphazardly collected from each plot. All attached green leaves were cut from the short shoots, measured for length and width, and cleaned of adhering epiphytes by gently scraping with a razor blade. The number of leaves per shoot, the lengths and widths of each blade, and the number of shoots per $\mathrm{m}^{2}$ were used to calculate a 2-sided LAI by dividing the surface area (in $\mathrm{m}^{2}$ ) of seagrass leaves by the area (in $\mathrm{m}^{2}$ ) of seagrass meadow. All leaves of a species from a plot were pooled and dried at $50^{\circ} \mathrm{C}$. Dried leaves were weighed and then ground to a fine powder using a ceramic mortar and pestle. Powdered samples were analyzed in duplicate for carbon and nitrogen content using a CHN analyzer. Phosphorus content of the powdered samples was determined by a
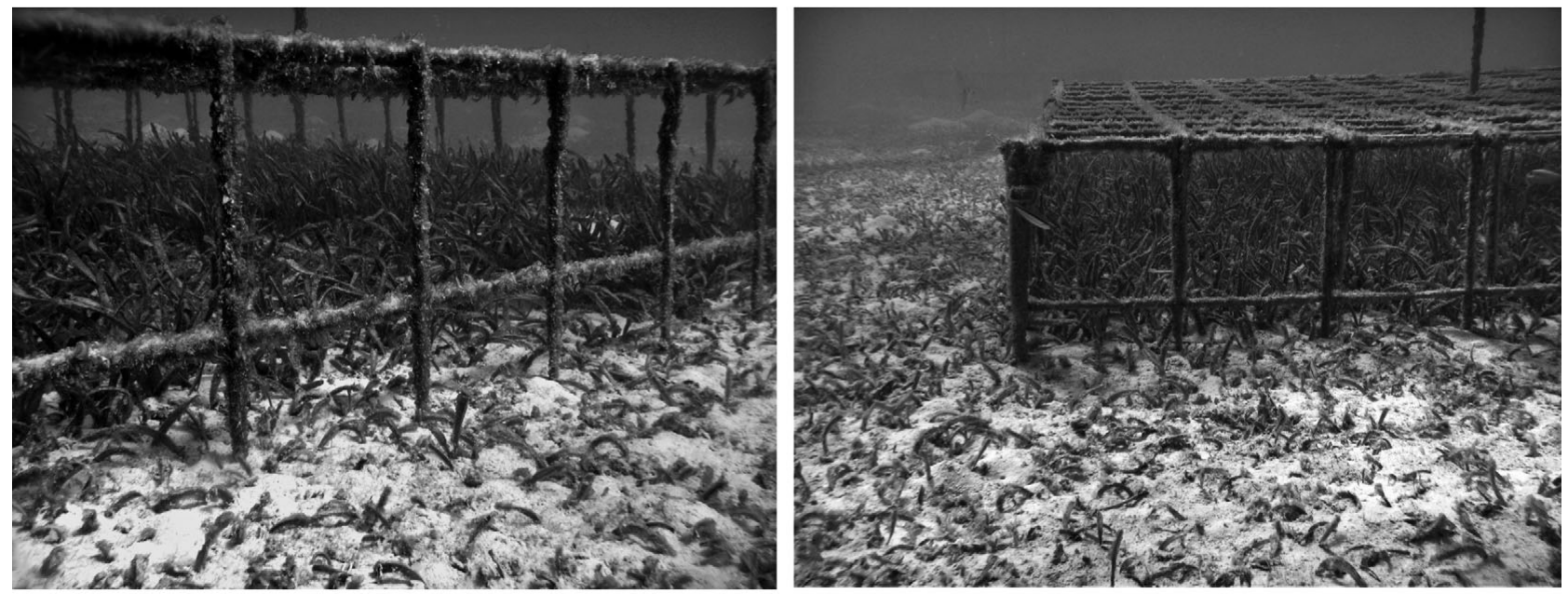

Fig. 1. Turtle exclusion cages 1 yr after initiation of the experiment. Note the exposed sediment and short, curled leaves outside of the exclosures compared to the longer, denser canopy of the seagrass Thalassia testudinum inside the cages 
dry-oxidation acid-hydrolysis extraction followed by a colorimetric analysis of phosphate concentration of the extract. Elemental content was calculated on a dry weight basis as (mass of element/dry weight of sample) $\times 100 \%$; elemental ratios were calculated on a mol:mol basis.

One year after the initiation of the experiment, we collected 3 haphazardly-placed $15.2 \mathrm{~cm}$ diameter core samples from within each plot, taking care not to damage seagrass shoots within the cores. Core tubes were inserted through the seagrass rhizosphere (ca. $40 \mathrm{~cm}$ deep). Cores were washed through a $5 \mathrm{~mm}$ mesh, and all seagrass material, living and dead, that was retained on the screens was collected, separated into green leaves, living belowground biomass, and necromass (dead and decaying seagrass material). Samples were then dried to constant weight in a $50^{\circ} \mathrm{C}$ oven and weighed. We calculated the mass of these components on an areal basis; we also calculated the ratio of the mass of green leaves to the total biomass of living seagrass for each core. Dried rhizome material was then stored in the dark at $-4^{\circ} \mathrm{C}$ until it was ground to a fine powder for subsequent analysis. Soluble carbohydrates in dried, ground rhizome tissues were determined using the MBTH (3-methyl-2-benzothiazolinone hydrazone hydrochloride) analysis method following Lee \& Dunton's (1997) seagrass tissue adaptation of the procedure described in Pakulski \& Benner (1992) for determining soluble carbohydrates in seawater.

Seagrass leaf production was measured in our plots 1 yr after treatment initiation using a modified leaf marking technique (Zieman 1974, Fourqurean et al. 2001). A $10 \times 20 \mathrm{~cm}$ quadrat was haphazardly placed within each plot. All seagrass short shoots within the quadrat were marked at the base of the leaves using a 20 gage hypodermic needle inserted through the short shoot on September 22, 2009. These marked short shoots were carefully harvested on October 15, 2009, and the new green leaf material below the marks was separated from the older green leaf material above the marks. All leaf material was cleaned of adhering epiphytes by gently scraping with a razor blade, and dried at $50^{\circ} \mathrm{C}$. From these data we calculated short shoot density (SS density, no. $\mathrm{m}^{-2}$ ), leaf mass (in $\mathrm{mg}$ ) per short shoot, standing crop of green leaves $\left(\mathrm{SC}, \mathrm{g} \mathrm{m}^{-2}\right.$ of seagrass meadow), leaf mass (in $\mathrm{g}$ ) as a fraction of total biomass (leaves plus nonphotosynthetic biomass). Production of leaf material per short shoot (SS productivity, mg $\mathrm{SS}^{-1} \mathrm{~d}^{-1}$ ), the mass of new leaves produced per mass of existing leaves over time (relative growth rate, $\mathrm{mg} \mathrm{g}^{-1} \mathrm{~d}^{-1}$ ), and areal production of new leaves over time ( $\mathrm{g} \mathrm{m}^{-2} \mathrm{~d}^{-1}$ ) were also calculated.

For each response variable, we calculated a plot mean from the within-plot subsamples before further analysis; these plot means were then used to test for differences attributable to megaherbivore exclusion. We tested for differences among means for treatments using 1-way ANOVA with Student-Newman-Keuls post hoc comparisons between treatments. In order to assess the differences within a treatment at the beginning and end of the experiments, we used a paired Student's $t$-test, with paired observations within the same plot in different years.

\section{RESULTS}

\section{Long-term monitoring}

In 1994, the CARICOMP monitoring stations were dense, extensive, Thalassia testudinum-dominated seagrass beds. Average leaf width $( \pm 1 \mathrm{SE})$ of the T. testudinum shoots decreased from $7.4 \pm 1.0 \mathrm{~mm}$ in 1994 to $2.2 \pm 0.9 \mathrm{~mm}$ in 2000 (Fig. 2). By 2000, mean leaf length averaged only $2.2 \pm 0.8 \mathrm{~cm}$, compared to $8.2 \pm 4.0 \mathrm{~cm}$ in 1994. There was also a decrease in shoot density over the same time period (data not shown), and the result
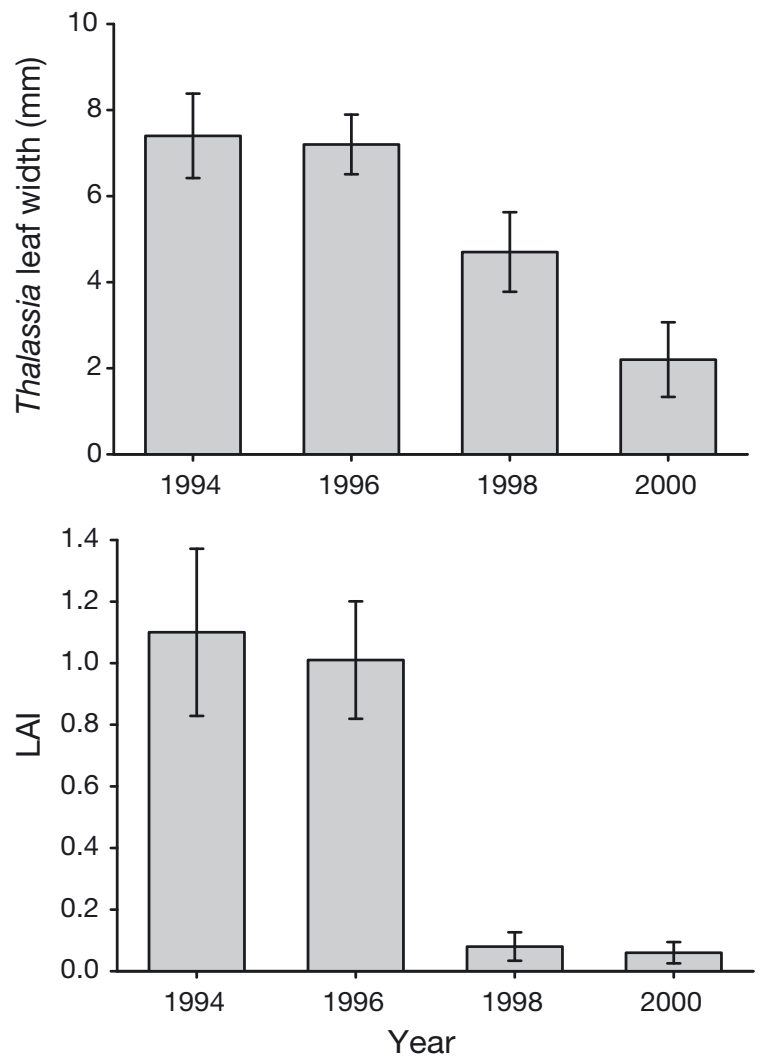

Fig. 2. Thalassia testudinum. Time series of leaf widths and Leaf Area Index (LAI) at the Caribbean Coastal Marine Productivity Program (CARICOMP) monitoring sites where the seagrass bed declined and collapsed. The LAI was calculated by dividing the surface area $\left(\mathrm{m}^{2}\right)$ of seagrass leaves by the area $\left(\mathrm{m}^{2}\right)$ of seagrass meadow. Error bars are \pm 1 SE. Data are averaged for the 2 CARICOMP sites 
of smaller, sparser shoots was a decrease in the LAI from $1.10 \pm 0.27$ in 1994 to $0.06 \pm 0.03$ in 2000 (Fig. 2). Seagrasses had not returned to this site by 2010 (authors' pers. obs.).

\section{Grazer exclusion experiments}

At our experimental site, $22 \mathrm{~km}$ from the CARICOMP monitoring sites, the morphology of the seagrass Thalassia testudinum was very different between the grazed area and the adjacent ungrazed seagrass bed. When we established the grazer exclusion cages and control areas in 2008, there was no difference in the density of short shoots in control plots compared to exclosures (mean density: $1068 \pm 47 \mathrm{SS}$ $\mathrm{m}^{-2}$ ), but the average densities in the plots were signif-

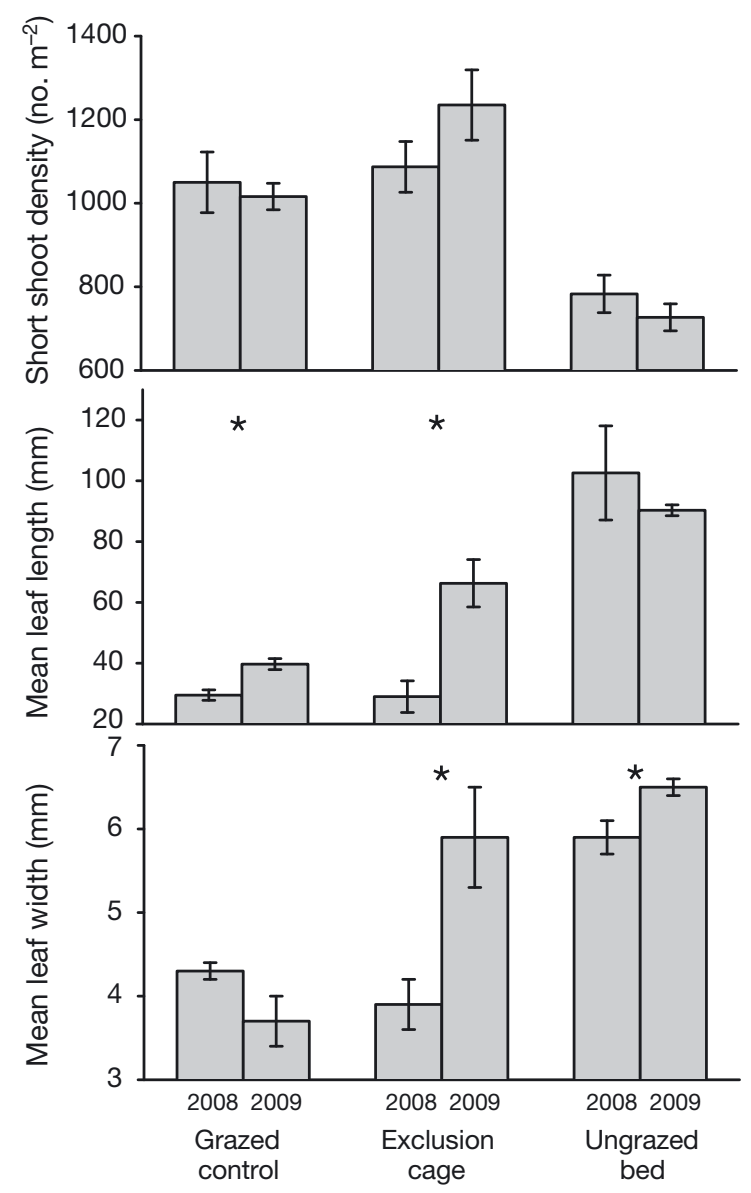

Fig. 3. Thalassia testudinum. Changes in short shoot density, leaf length, and leaf width in response to exclusion of turtle grazers for 1 yr. Error bars are \pm 1 SE. Grazed control and exclusion cage plots were established in a heavily grazed seagrass meadow in September 2008. Ungrazed bed data are for a nearby (ca. $20 \mathrm{~m}$ distant) plot that was not heavily grazed. For each bar, $\mathrm{n}=3$. Asterisks denote significant differences (paired $t$-test, $\mathrm{p}<0.05$ ) between years icantly higher than those observed in the nearby ungrazed seagrass bed $\left(819 \pm 58 \mathrm{SS} \mathrm{m}^{-2}\right.$; Fig. 3). Similarly, there were no differences in the mean leaf length or width in control or exclosure plots, but leaves in the plots were shorter $(29.3 \pm 2.7 \mathrm{~mm}$ compared to $102.6 \pm$ $16.7 \mathrm{~mm}$ ) and narrower ( $4.1 \pm 0.2 \mathrm{~mm}$ compared to 5.9 $\pm 0.2 \mathrm{~mm}$ ) than found in the adjacent ungrazed bed. After one year of protection from grazing by sea turtles, the leaves of the $T$. testudinum in the grazing exclusion cages were significantly longer and wider than those found in the grazed control plots (Table 1a, Fig. 3); the leaf lengths in the grazing exclusion cages approached the lengths of the $T$. testudinum in the nearby ungrazed area and the leaf widths were as wide as those found in the ungrazed area. However, there were no significant differences in the seagrass short shoot density between grazed controls and the ungrazed exclusion cages. Clearly, preventing sea turtles from grazing increased the size of the leaves on seagrass short shoots (Fig. 1).

Destructive sampling after 1 yr of excluding sea turtle grazers from the seagrass beds confirmed that shoot morphology, living biomass of seagrasses, LAI, and seagrass productivity all increased compared to the grazed controls; indeed many of these measures of the robustness of the seagrasses approached the values in the nearby ungrazed seagrass bed (Table 1a). The amount of leaf mass per short shoot of Thalassia testudinum in the exclusion cage plots increased more than 3 -fold over the grazed controls, as did the leaf fraction of the total plant biomass. Larger, leafier short shoots of $T$. testudinum in the grazer exclusion cages resulted in an increase in the standing crop of seagrass leaves from $13.2 \pm 0.6 \mathrm{~g} \mathrm{~m}^{-2}$ in grazed controls to $46.8 \pm$ $9.4 \mathrm{~g} \mathrm{~m}^{-2}$ in grazer exclusion cages. Two other seagrasses (Halodule sp. and Syringodium filiforme) also occurred in the ungrazed bed with a mean combined standing crop of these other species of $3.9 \pm 1.3 \mathrm{~g} \mathrm{~m}^{-2}$ intermixed with the dominant $T$. testudinum, which had a standing crop of $47.1 \pm 6.6 \mathrm{~g} \mathrm{~m}^{-2}$; these other species were absent from the grazed control plots and the grazer exclusion cages.

LAI in the grazer exclusion plots as well as the nearby ungrazed bed was more than twice as high as in the grazed control plots (Table 1a). Because the short shoots were larger and there was more leaf biomass in the grazer exclusion cages, rates of primary production per short shoot and per $\mathrm{m}^{2}$ were 3 times higher in the grazer exclusion cages compared to the grazed control plots. However, relative growth rate was the same in control and ungrazed exclusion cage plots.

The amount of living belowground biomass was not greater in the grazer exclusion compared to the grazed control plots, although the belowground biomass was 
Table 1. Thalassia testudinum. Comparison of (a) short shoot (SS) density, leaf biomass, leaf production rates, leaf morphology, and Leaf Area Index, and (b) the nutrient content and molar nutrient ratios of leaves and the soluble carbohydrate concentration per gram of rhizomes within the ungrazed bed, in the grazed control plots, and in the turtle exclusion cages after 1 yr of turtle exclusion. Relative growth rate is the mass of new leaves (mg) per mass of existing leaves $(\mathrm{g}) \mathrm{d}^{-1}$; for an explanation of Leaf Area Index see Fig. 2. DW: dry weight. Values are treatment means \pm 1 SE. Significant differences (in bold type) were assessed with 1-way ANOVAs, and differences among treatments were determined by Student-Newman-Keuls post hoc tests. Treatments that share a superscripted letter were not significantly different at $\alpha=0.05$

\begin{tabular}{|c|c|c|c|c|c|}
\hline & AN & results & & - Treatment & \\
\hline & $F$ & $\mathrm{p}$ & $\begin{array}{l}\text { Grazed control } \\
\qquad \mathrm{n}=3\end{array}$ & $\begin{array}{l}\text { Exclusion cages } \\
\qquad \mathrm{n}=3\end{array}$ & $\begin{array}{l}\text { Ungrazed bed } \\
\qquad \mathrm{n}=3\end{array}$ \\
\hline a) & & & & & \\
\hline SS density (no. $\mathrm{m}^{-2}$ ) & 0.50 & 0.632 & $1033 \pm 17^{a}$ & $1150 \pm 284^{a}$ & $883 \pm 164^{\mathrm{a}}$ \\
\hline Leaf mass per SS $\left(\mathrm{mg} \mathrm{SS}^{-1}\right)$ & 24.75 & 0.001 & $12.8 \pm 0.6^{\mathrm{a}}$ & $43.4 \pm 7.0^{\mathrm{b}}$ & $54.2 \pm 2.4^{\mathrm{b}}$ \\
\hline Leaf mass ( $\%$ of total mass) & 12.29 & 0.008 & $2.0 \pm 0.6^{\mathrm{a}}$ & $7.1 \pm 0.3^{\mathrm{b}}$ & $9.3 \pm 1.7^{\mathrm{b}}$ \\
\hline Standing crop $\left(\mathrm{g} \mathrm{m}^{-2}\right)$ & 8.62 & 0.017 & $13.2 \pm 0.6^{\mathrm{a}}$ & $46.8 \pm 9.4^{b}$ & $47.1 \pm 6.6^{b}$ \\
\hline Belowground biomass $\left(\mathrm{g} \mathrm{m}^{-2}\right)$ & 7.24 & 0.020 & $520 \pm 72^{\mathrm{a}}$ & $645 \pm 65^{\mathrm{a}}$ & $986 \pm 121^{\mathrm{b}}$ \\
\hline Belowground necromass $\left(\mathrm{g} \mathrm{m}^{-2}\right)$ & 8.10 & 0.020 & $894 \pm 136^{\mathrm{a}}$ & $1112 \pm 151^{\mathrm{a}}$ & $381 \pm 104^{\mathrm{b}}$ \\
\hline $\mathrm{SS}$ productivity $\left(\mathrm{mg} \mathrm{SS} \mathrm{d}^{-1}\right)$ & 8.47 & 0.018 & $0.41 \pm 0.02^{\mathrm{a}}$ & $1.34 \pm 0.31^{\mathrm{b}}$ & $1.31 \pm 0.06^{\mathrm{b}}$ \\
\hline Relative growth rate $\left(\mathrm{mg} \mathrm{g} \mathrm{d}^{-1}\right)$ & 9.45 & 0.014 & $32.1 \pm 0.9^{\mathrm{a}}$ & $30.2 \pm 2.0^{\mathrm{a}}$ & $24.2 \pm 0.7^{b}$ \\
\hline Areal productivity $\left(\mathrm{g} \mathrm{m}^{-2} \mathrm{~d}^{-1}\right)$ & 8.95 & 0.016 & $0.42 \pm 0.01^{\mathrm{a}}$ & $1.39 \pm 0.25^{\mathrm{b}}$ & $1.13 \pm 0.16^{\mathrm{b}}$ \\
\hline Leaf length $(\mathrm{mm})$ & 11.2 & 0.010 & $39.7 \pm 1.8^{\mathrm{a}}$ & $66.3 \pm 7.8^{\mathrm{b}}$ & $90.3 \pm 1.8^{\mathrm{c}}$ \\
\hline Leaf width (mm) & 28.5 & 0.001 & $3.8 \pm 0.3^{\mathrm{a}}$ & $5.9 \pm 0.6^{\mathrm{b}}$ & $6.5 \pm 0.1^{\mathrm{b}}$ \\
\hline Leaf Area Index & 8.90 & 0.016 & $0.21 \pm 0.04^{\mathrm{a}}$ & $0.50 \pm 0.07^{\mathrm{b}}$ & $0.47 \pm 0.05^{\mathrm{b}}$ \\
\hline b) & & & & & \\
\hline Carbon content (\% DW) & 2.69 & 0.147 & $34.7 \pm 1.1^{\mathrm{a}}$ & $35.2 \pm 0.7^{\mathrm{a}}$ & $37.2 \pm 0.3^{\mathrm{a}}$ \\
\hline Nitrogen content (\% DW) & 33.16 & 0.001 & $2.52 \pm 0.09^{\mathrm{a}}$ & $1.89 \pm 0.07^{\mathrm{b}}$ & $1.67 \pm 0.07^{b}$ \\
\hline Phosphorus content (\% DW) & 20.16 & 0.002 & $0.145 \pm 008^{\mathrm{a}}$ & $0.090 \pm 0.001^{\mathrm{b}}$ & $0.114 \pm 0.007^{\mathrm{c}}$ \\
\hline$C: N$ & 64.71 & $<0.001$ & $16.1 \pm 0.4^{\mathrm{a}}$ & $21.8 \pm 0.6^{\mathrm{b}}$ & $26.1 \pm 0.9^{\mathrm{c}}$ \\
\hline $\mathrm{C}: \mathrm{P}$ & 27.94 & 0.001 & $622 \pm 040^{\mathrm{a}}$ & $1006 \pm 90^{\mathrm{b}}$ & $852 \pm 48^{\mathrm{c}}$ \\
\hline $\mathrm{N}: \mathrm{P}$ & 17.32 & 0.003 & $38.6 \pm 2.0^{\mathrm{a}}$ & $46.2 \pm 1.3^{b}$ & $32.6 \pm 1.6^{\mathrm{c}}$ \\
\hline Soluble carbohydrate (mg C g ${ }^{-1}$ rhizome DW) & 8.92 & 0.016 & $86.7 \pm 6.4^{\mathrm{a}}$ & $117.3 \pm 6.2^{\mathrm{b}}$ & $129.9 \pm 9.3^{b}$ \\
\hline
\end{tabular}

higher in the nearby ungrazed bed than in both experimental plots (Table 1a). Conversely, there was roughly 3 times more mass of belowground dead and decomposing seagrass necromass in the experimental plots compared to the nearby ungrazed seagrass bed.

When we established the experimental plots in the heavily grazed area in September 2008, there were no differences in the elemental content of leaves of Thalassia testudinum between grazed control plots and grazer exclusion cages ( $t$-test, $t$ for all comparisons $<0.75, \mathrm{p}>0.51$ ). Seagrass leaves contained $41.1 \pm 0.2 \%$ C, $2.42 \pm 0.1 \% \mathrm{~N}$, and $0.126 \pm 0.006 \% \mathrm{P}$; average molar ratios $( \pm 1 \mathrm{SE}$ ) of nutrient content were $20.0 \pm 0.6$ for $C: N, 854 \pm 39$ for $C: P$, and $42.9 \pm 1.7$ for $N: P$. In the nearby ungrazed seagrass bed, $\mathrm{C}$ content of $T$. testudinum leaves $(40.1 \%)$ was similar to the $C$ content in the experimental plots in the grazed area, but the $\mathrm{N}$ $(1.57 \%)$ and $\mathrm{P}(0.090 \%)$ contents were significantly lower. One year after establishing the sea turtle exclusion plots, the elemental content of the seagrass leaves protected from herbivory had lower concentrations of $\mathrm{N}$ and $\mathrm{P}$ than the grazed control plots, but $\mathrm{C}$ concentrations did not change (Table $1 \mathrm{~b}$ ); the $\mathrm{N}$ content of the seagrass from the exclusion plots became similar to the $\mathrm{N}$ content of the seagrasses from the nearby ungrazed bed. In contrast, P content of the seagrass leaves from the grazer exclusion cages was lower than the P content in either the grazed control plots or the nearby ungrazed bed. The C:N ratio was lowest in the grazed control plots, intermediate in the grazer exclusion cages, and highest in the nearby ungrazed bed. The $\mathrm{C}: \mathrm{P}$ ratio was also lowest in the grazed control plots, but the C:P ratio of the grazer exclusion cages was higher than the ungrazed bed. The N:P ratio, in contrast, was lowest in the ungrazed bed and highest in the exclusion cages.

The levels of soluble carbohydrates in the rhizomes of Thalassia testudinum were $86.7 \pm 6.4 \mathrm{mg} \mathrm{C} \mathrm{g}^{-1}$ in grazed control plots, which was significantly lower than the soluble carbohydrate concentration in the rhizomes from grazer exclusion cages $(117.3 \pm 6.2 \mathrm{mg}$ $\left.\mathrm{g}^{-1}\right)$; the concentrations in grazer exclusion plots were similar to those in the nearby ungrazed bed (Table $1 \mathrm{~b}$ ).

\section{DISCUSSION}

Protecting experimental plots from grazing by sea turtles caused an increase in the biomass of seagrasses and an increase in the structural complexity of the seagrass canopy, as the length and width of the seagrass blades increased. Plots from which turtles were 
excluded had higher rates of primary production, on a per-shoot or areal basis, but relative growth rate was not affected. The leaves of seagrasses protected from grazing had lower concentrations of $\mathrm{N}$ and $\mathrm{P}$ than grazed blades, but the storage of soluble carbohydrates in the rhizomes increased markedly in the protected plots. The continued grazing of sea turtles in our plots did not lead to significant changes in seagrass shoot density or in nutrient content over the 1 yr of our experiment, suggesting that the continued grazing at this site was not sufficient to cause further degradation of the remaining seagrasses in the grazed area over this time span.

\section{Sea turtles and loss seagrass beds}

Our results are consistent with the hypothesis that overgrazing by sea turtles caused the loss of the seagrass meadows at the CARICOMP monitoring site in Bermuda in the late 1990s, but our experiments to date have not been sufficient to confirm this hypothesis. The decreased canopy cover and the shorter, thinner seagrass leaves induced by sea turtle grazing in our experimental plots suggest that the progressive narrowing and thinning of seagrasses observed before the collapse of the major offshore seagrass beds at the CARICOMP sites in the 1990s (Fig. 2) may have been in response to repeated grazing of that seagrass bed. Others have reported that leaves of Thalassia testudinum are narrower in repeatedly grazed patches than the ungrazed surrounding seagrass meadow (Zieman et al. 1984) and that experimental clipping to mimic turtle grazing leads to narrower leaf blades (Moran \& Bjorndal 2005). Relaxation of grazing pressure reduces this effect: exclusion of turtles for 3 mo from a heavily grazed seagrass meadow in the US Virgin Islands led to wider leaves (Williams 1988). Our current experiment corroborates the findings of Williams (1988): We show that the decrease in blade width caused by grazing is a reversible process (Fig. 3), i.e. when grazing by largebodied herbivores is stopped, the leaf widths increase to match the surrounding ungrazed areas.

Sea turtles are not the only herbivores in seagrass ecosystems that have the potential to structure seagrass meadows (see Heck \& Valentine 2006 for review). Seasonal increases in the abundance of the herbivorous purple sea urchin Lytechinus variegatus can consume all of the aboveground biomass of some seagrass beds in the northern Gulf of Mexico (Valentine \& Heck 1991), and population explosions of this species can lead to the local extinction of seagrasses (Rose et al. 1999). Grazing by herbivorous fish and sea urchins that shelter on coral reefs can cause barren halos in the seagrass beds surrounding coral reefs
(Tribble 1981), and selective grazing by herbivorous fish can control the species composition of seagrass beds around reefs (Armitage \& Fourqurean 2006). Herbivorous geese can remove enough seagrass biomass to allow erosion of the shallow intertidal zone and therefore promote long-term persistence of seagrasses in shoaling seagrass meadows (Nacken \& Reise 2000). However, if sea turtles, or other grazers, are responsible for the recent losses of seagrasses from the Bermuda Platform (Murdoch et al. 2007), the spatial scale of the influence of herbivores in Bermuda is much greater than that in any other seagrass ecosystem.

\section{Mechanism of seagrass decline}

As seagrass leaves age, they become depleted of nutrients, and this may be the reason why sea turtles clip seagrass blades from feeding patches and then repeatedly graze on the relatively high-nutrient young leaf tissue (Bjorndal 1980, 1997). Nutrient content of young seagrass leaves is a function of the availability of nutrients relative to the demand necessary to build new biomass (Duarte 1990, Fourqurean et al. 1992). Thayer et al. (1984) hypothesized that nitrogen content of young seagrass leaves should decrease as a consequence of repeated grazing, and that this decrease could affect rates of primary productivity if nitrogen supplies were depleted, providing a cue to the turtles to abandon the less nutritious grazing patches. However, Moran \& Bjorndal (2007) simulated turtle grazing for 16 mo and found no decrease over that time interval in the $\mathrm{N}$ content of Thalassia testudinum. Our data (Table 1b) suggest that even prolonged repeated grazing for at least 3 yr (2006, when we first documented the existence of this grazed area, to 2009, at the end of the first year of our experiments) did not result in a decrease in the $\mathrm{N}$ content of the seagrass leaves; in fact, we see an increase in $\mathrm{N}$ content relative to ungrazed seagrasses. This may simply be a consequence of accumulation of older leaves with lower $\mathrm{N}$ content in ungrazed plots. The decrease in $\mathrm{N}$ content of seagrasses in our grazer exclusion cages could also suggest that ambient $\mathrm{N}$ supply was sufficient to support the growth of new seagrass leaves at the lower rate of primary productivity caused by the grazing, but at higher rates of primary productivity, the supply of $\mathrm{N}$ decreased relative to demand, so that the $\mathrm{N}$ content decreased in the plots protected from grazing.

We believe the decline in primary productivity and seagrass short shoot size caused by repeated grazing is a consequence of an altered carbon balance in the seagrasses, rather than of loss of nutrients from the seagrass ecosystem. Much of the biomass of seagrasses, 
especially Thalassia testudinum, is in the form of nonphotosynthetic, belowground tissues that place a respiratory burden on the plant that must be balanced by the photosynthesis of the leaves (Fourqurean \& Zieman 1991). In the rhizomes of seagrasses that were protected from grazing, the soluble carbohydrate concentrations increased by $35 \%$ compared to grazed controls (Table $1 \mathrm{~b}$ ). The soluble carbohydrates stored in rhizomes are an important photosynthate reservoir that supports growth and maintenance of other tissues during periods of low photosynthetic production (Dawes \& Lawrence 1980, Pirc 1985). Indeed, the belowground biomass was depressed in grazed plots, a pattern observed in the offshore decline of seagrass beds in the 1990s (Murdoch et al. 2007). Rhizome soluble carbohydrate reserves are critical for survival and regrowth during extended periods of light reduction or in response to defoliation (Dawes \& Lawrence 1979, Drew 1983, Dawes \& Guiry 1992). The differences we found in soluble carbohydrate levels between grazed and ungrazed seagrasses (Table $1 \mathrm{~b}$ ) are comparable to the differences between $95 \%$ incident light reduction and full sunlight in an experiment in a T. testudinum meadow in Texas (Lee \& Dunton 1997). It is likely that the removal of the photosynthetic potential of leaves by grazing sea turtles decreased the production and storage of photosynthate in the seagrasses, slowing their growth and reducing the ability of the seagrasses to recover from unfavorable environmental conditions. This makes the effects on seagrasses of the grazing by sea turtles similar to the effects of severe light reduction. The decrease in width of seagrasses seen in our experiments and reported in the literature in response to sea turtle grazing parallels the large decreases in leaf width of $T$. testudinum in response to severe light reduction (Lee \& Dunton 1997).

The decrease in photosynthetic capacity caused by grazing could be of particular consequence in Bermuda compared to other locations where sea turtles feed on seagrasses. Seagrasses have a very high light requirement compared to phytoplankton, macroalgae, or even low-light adapted terrestrial angiosperms, because of the large amounts of belowground, nonphotosynthetic biomass and the saturated conditions of seagrass soils that lead to very low oxygen concentrations surrounding those belowground plant parts (Duarte 1991). In Bermuda, at the poleward extreme of the range for Thalassia testudinum, there is less solar irradiance to drive photosynthesis than at more tropical locales, so the removal of photosynthetic leaves should have a greater consequence than elsewhere.

The loss of the large offshore seagrass beds in the late 1990s (Fig. 2) was the endpoint of a process that caused the thinning of the density of seagrass short shoots and a decrease in the leaf width and leaf length of the remaining shoots, with a concomitant loss in primary production of that seagrass meadow. These symptoms are consistent with a negative carbon balance in the seagrasses and are what we would expect to observe if the light to the seagrass meadow were reduced. However, we observed no decreases in water clarity at CARICOMP sites during the period of loss (S. R. Smith unpubl. data), and as of 2010 , over $30 \%$ of surface irradiance still penetrates to the bottom at the location of the former seagrass bed (S. Manuel \& K. A. Coates unpubl. data) and is sufficient to support the growth of Thalassia testudinum. Previously published studies (e.g. Zieman et al. 1984, Williams 1988, Moran \& Bjorndal 2005) have established that the same changes in shoot morphology, density, and productivity we would expect under conditions of light reduction also characterize the response of seagrasses to repeated grazing by green sea turtles. Our experimental work shows that these symptoms can be reversed if heavily grazed seagrasses are protected from grazing. While this cannot be considered absolute proof that seagrass loss at the CARICOMP sites was due to overgrazing by turtles, the symptoms observed prior to the loss of those meadows are consistent with this mechanism.

The former CARICOMP monitoring sites and our experimental site are not unique in Bermuda, as there are many seagrass meadows that show evidence of severe, repeated grazing of green sea turtles on the platform (authors' pers. obs.). As we learned from observing the heavily grazed seagrass bed at our experimental site near Chub Head Beacon, the seagrasses can survive many years of repeated grazing. During the year of our experiment, seagrass short shoot density and the length and width of the seagrasses in our unprotected control plots did not continue to decline (Fig. 3). It would appear that some other environmental factor is important in determining whether seagrass beds can survive heavy sea turtle grazing pressure. Possibly, the small sizes of the CARICOMP seagrass beds may have exacerbated the grazing impacts, while our experimental seagrass bed is much larger and potentially more resilient to grazing pressure. At other heavily grazed locations around Bermuda, we have observed enhanced bioturbation and erosion of the sediments from the rhizosphere of the thin, sparse-canopied beds, which destabilize the rhizosphere and makes it susceptible to disturbance by storm waves and bioturbation. After this removal of the rhizosphere, remnants of roots of Thalassia testudinum project above the new sediment surface, in a manner similar to what we observed at the CARICOMP monitoring sites after the seagrass beds collapsed. 


\section{Sea turtle conservation and seagrasses}

We suggest that the recent rebound of green sea turtle populations in the Atlantic (Chaloupka et al. 2008) may have consequences for the seagrass resources on which those populations depend, but that those consequences may not all be positive, as postulated by Jackson et al. (2001). In some locations where seagrass beds have extensive, continuous distributions, increases in sea turtle populations may indeed have little or even beneficial impact on seagrass communities. For example, in the Bahamas, the carrying capacity of the widely occurring Thalassia testudinum meadows

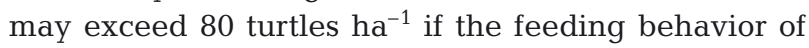
the turtles does not lead to loss of the seagrass meadows (Moran \& Bjorndal 2005). In other locations with more limited distribution of seagrass resources, sea turtle populations and their demands exceed the ability of the seagrass meadows to provision them. Williams (1988) found that the combined effects of sea turtle feeding and anchor damage were leading to the decline of the few seagrass meadows in 2 bays in the US Virgin Islands, and predicted negative consequences for the turtle population if this loss were to continue. In Bermuda, the distribution of tropical seagrass meadows is restricted in terms of area compared to similar coastal environments in more tropical locations. The rapid loss of the seagrass resources documented in the late 1990s (Murdoch et al. 2007), whether caused by overgrazing by the sea turtle population or due to some other as yet unidentified driver, could have dire consequences for the juvenile turtle population of the island, since the nearest tropical seagrass beds are over $1000 \mathrm{~km}$ away.

Acknowledgements. This work was funded by the Department of Conservation Services, Government of Bermuda and B. Dilke, a private benefactor. Laboratory analyses were coordinated by P. Parker. A. Nash designed, built and installed the cages, and was instrumental in all of our field work. M. Shailer assisted in field GIS applications. Funding for W.J.K. was provided by the Center for Coastal Fisheries and Habitat Research, NCCOS, NOS, NOAA. This is contribution \# 498 of the Southeast Environmental Research Center, Florida International University, and contribution \# 177 from the Bermuda Biodiversity Project, Bermuda Aquarium, Museum \& Zoo in the Department of Conservation Services.

\section{LITERATURE CITED}

Alcolado PM, Alleng G, Bonair K, Bone D and others (2001) The Caribbean Coastal Marine Productivity Program (CARICOMP). Bull Mar Sci 69:819-829

Armitage AR, Fourqurean JW (2006) The short-term influence of herbivory near patch reefs varies between seagrass species. J Exp Mar Biol Ecol 339:65-74

Bjorndal KA (1980) Nutrition and grazing behavior of the green turtle Chelonia mydas. Mar Biol 56:147-154
Bjorndal KA (1997) Foraging ecology and nutrition of sea turtles. In: Lutz PL, Musick JA (eds) The biology of sea turtles. CRC Press, Boca Raton, FL, p 199-231

Bjorndal KA, Jackson JBC (2003) Roles of sea turtles in marine ecosystems: reconstructing the past. In: Lutz PL, Musick J, Wyneken J (eds) Biology of sea turtles, Vol 2. CRC Press, Boca Raton, FL, p 259-273

CARICOMP (1997) Variation in ecological parameters of Thalassia testudinum across the CARICOMP network. Proc 8th Int Coral Reef Symp 1:663-668

> Chaloupka M, Bjorndal KA, Balazs GH, Bolten AB and others (2008) Encouraging outlook for recovery of a once severely exploited marine megaherbivore. Glob Ecol Biogeogr 17:297-304

> Dawes CJ, Guiry MD (1992) Proximate constituents in the seagrasses Zostera marina and $Z$. noltii in Ireland: seasonal changes and the effect of blade removal. PSZNI: Mar Ecol 13:307-315

Dawes CJ, Lawrence JM (1979) Effects of blade removal on the proximate composition of the rhizome of the seagrass Thalassia testudinum Banks ex König. Aquat Bot 7: $255-266$

> Dawes CJ, Lawrence JM (1980) Seasonal changes in the proximate constituents of the seagrasses Thalassia testudinum, Halodule wrightii, and Syringodium filiforme. Aquat Bot 8:371-380

> Drew EA (1983) Sugars, cyclitols and seagrass phylogeny. Aquat Bot 15:387-408

> Duarte CM (1990) Seagrass nutrient content. Mar Ecol Prog Ser 67:201-207

- Duarte CM (1991) Seagrass depth limits. Aquat Bot 40: 363-377

Fourqurean JW, Zieman JC (1991) Photosynthesis, respiration and whole plant carbon budget of the seagrass Thalassia testudinum. Mar Ecol Prog Ser 69:161-170

Fourqurean JW, Zieman JC, Powell GVN (1992) Relationships between porewater nutrients and seagrasses in a subtropical carbonate environment. Mar Biol 114:57-65

> Fourqurean JW, Willsie AW, Rose CD, Rutten LM (2001) Spatial and temporal pattern in seagrass community composition and productivity in south Florida. Mar Biol 138: 341-354

> Fourqurean JW, Escorcia SP, Anderson WT, Zieman JC (2005) Spatial and seasonal variability in elemental content, $\delta^{13} \mathrm{C}$, and $\delta^{15} \mathrm{~N}$ of Thalassia testudinum from south Florida and its implications for ecosystem studies. Estuaries 28: 447-461

Godley BJ, Broderick AC, Campbell LM, Ranger S, Richardson PB (2004) An assessment of the status and exploitation of marine turtles in Bermuda. In: An assessment of the status and exploitation of marine turtle in the UK overseas territories in the wider Caribbean. Final Project Report for the Department of Environment, Food and Rural Affairs and the Foreign and Commonwealth Office, London, p 78-95

Heck KL, Valentine JF (2006) Plant-herbivore interactions in seagrass meadows. J Exp Mar Biol Ecol 330:420-436

> Jackson JBC, Kirby MX, Berger WH, Bjorndahl KA and others (2001) Historical overfishing and the recent collapse of coastal ecosystems. Science 293:629-638

> Lee KS, Dunton KH (1997) Effects of in situ light reduction on the maintenance, growth and partitioning of carbon resources in Thalassia testudinum Banks ex König. J Exp Mar Biol Ecol 210:53-73

Moran KL, Bjorndal KA (2005) Simulated green turtle grazing affects structure and productivity of seagrass pastures. Mar Ecol Prog Ser 305:235-247

> Moran KL, Bjorndal KA (2007) Simulated green turtle grazing affects nutrient composition of the seagrass Thalassia 
testudinum. Mar Biol 150:1083-1092

Murdoch TJT, Glasspool AF, Outerbridge M, Ward J and others (2007) Large-scale decline in offshore seagrass meadows in Bermuda. Mar Ecol Prog Ser 339:123-130

Nacken N, Reise K (2000) Effects of herbivorous birds on intertidal seagrass beds in the northern Wadden Sea. Helgol Mar Res 54:87-94

Pakulski JD, Benner R (1992) An improved method for the hydrolysis and MBTH analysis of dissolved and particulate carbohydrates in seawater. Mar Chem 40:143-160

Pirc H (1985) Growth dynamics in Posidonia oceanica Delile. I. Seasonal changes of soluble carbohydrates, starch, free amino acids, nitrogen and organic anions in different parts of the plant. PSZNI: Mar Ecol 6:141-165

Rose CD, Sharp WS, Kenworthy WJ, Hunt JH and others (1999) Overgrazing of a large seagrass bed by the sea urchin Lytechinus variegatus in outer Florida Bay. Mar Ecol Prog Ser 190:211-222

Smith SR (1998) Bermuda. In: Kjerve B (ed) UNESCO, 1998 CARICOMP-Caribbean coral reef, seagrass and mangrove sites. Coastal region and small island papers 3 ,
UNESCO, Paris, p 247-257

> Thayer GW, Bjorndal KA, Ogden JC, Williams SL, Zieman JC (1984) Role of larger herbivores in seagrass communities. Estuaries 7:351-376

Tribble GW (1981) Reef-based herbivores and the distribution of two seagrasses (Syringodium filiforme and Thalassia testudinum) in the San Blas Islands (western Caribbean). Mar Biol 65:277-281

> Valentine JF, Heck KL (1991) The role of sea urchin grazing in regulating subtropical seagrass meadows: evidence from field manipulations in the northern Gulf of Mexico. J Exp Mar Biol Ecol 154:215-230

Williams SL (1988) Thalassia testudinum productivity and grazing by green turtles in a highly disturbed seagrass bed. Mar Biol 98:447-455

Zieman JC (1974) Methods for the study of the growth and production of turtle grass, Thalassia testudinum König. Aquaculture 4:139-143

Zieman JC, Iverson RL, Ogden JC (1984) Herbivory effects on Thalassia testudinum leaf growth and nitrogen content. Mar Ecol Prog Ser 15:151-158

Submitted: April 30, 2010; Accepted: September 28, 2010 Proofs received from author(s): November 22, 2010
Editorial responsibility: Hans Heinrich Janssen, Oldendorf/Luhe, Germany 